\title{
Detecting human-knapped flint with marine high-resolution reflection seismics: A preliminary study of new possibilities for subsea mapping of submerged Stone Age sites
}

Ole Grøn*1,2, Lars Ole Boldreel ${ }^{1}$, Jean-Pierre Hermand ${ }^{3}$, Hugo Rasmussen ${ }^{4}$, Antonio Dell'Anno ${ }^{5}$, Deborah Cvikel $^{6}$, Ehud Galili ${ }^{7}$, Bo Madsen ${ }^{8}$ and Egon Nørmark ${ }^{9}$

${ }^{1}$ Department of Geosciences and Natural Resource Management, University of Copenhagen, $\emptyset$ stervoldgade 10, DK 1250 Copenhagen K, Denmark

${ }^{2}$ Culture E Preservation, Markstien 23, 9690 Fjerritslev, Denmark

${ }^{3}$ Acoustics Ẽ Environmental HydroAcoustics Lab, Université libre de Bruxelles (ULB), Avenue F.D. Roosevelt 50 - CP 165/57, B-1050 Brussels, Belgium

${ }^{4}$ Danish Nitro-Electric, Allegade 3, 7600 Struer, Denmark

${ }^{5}$ Department of Life and Environmental Sciences (DiSVA), Università Politecnica delle Marche (UNIVPM), Via Brecce Bianche, 60131 Ancona, Italy

${ }^{6}$ Leon Recanati Institute for Maritime Studies, University of Haifa, Haifa 3498838, Israel

${ }^{7}$ The Zinman Institute of Archaeology, University of Haifa, 199 Aba-Hushi Avenue, Haifa 3498838, Israel

${ }^{8}$ East Jutland Museum, Stemannsgade 2, 8900 Randers C, Denmark

${ }^{9}$ Department of Geoscience, Aarhus University, Høeg-Guldbergs Gade 2, 8000 Aarhus C, Denmark

\section{Abstract}

Seismic high-resolution Chirp profiles from the welldocumented submerged Stone Age settlement Atlit-Yam, located off Israel's Carmel coast, display systematic disturbances within the water column not related to sea-floor cavitation, vegetation, fish shoals, gas or salinity/temperature differences, where flint debitage from the Stone Age site had been verified archaeologically. A preliminary series of controlled experiments, using identical acquisition parameters, strongly indicate that human-knapped flint debitage lying on the sea floor, or embedded within its sediments, produces similar significant responses in the water column. Flint pieces cracked naturally by thermal or geological processes appear not to do so. Laboratory experiments, finite element modelling and controlled experiments conducted in open water on the response to broad-spectrum acoustic signals point to an excited resonance response within humanknapped flint even for sediment embedded debitage, with acoustic signals within the $2-20 \mathrm{kHz}$ interval. The disturbances observed in the water column on the seismic profiles recorded at Atlit-Yam are, therefore, based on these results, interpreted as resonance from human-knapped flint debitage covered by up to $1.5 \mathrm{~m}$ of sand. Such a principle,

\footnotetext{
* Corresponding author. Email address: og@ign.ku.dk
}

if substantiated by further research, should facilitate efficient and precise mapping of submerged Stone Age sites.

Keywords: maritime archaeology, Stone Age, survey methods, acoustic mapping

\section{Introduction}

Acoustic methods are increasingly being used to map archaeological sites under water. The emphasis so far has been on side-scanners and multibeam systems, which are well-suited to detecting features visible above and on the sea floor (Bates et al., 2011). These methods cannot be applied when the archaeological sites are covered by sediments. For this purpose, high-resolution sub-bottom profilers (highresolution reflection seismic methods) have begun to play a role in the detection of archaeological sites (such as shipwrecks and pole structures) embedded in sea-floor sediments (Plets et al., 2009; Grøn et al., 2015; Grøn et al., 2018; Boldreel et al., 2018).

Acoustic discrimination between cultural layers of submerged Stone Age sites and natural layers of 


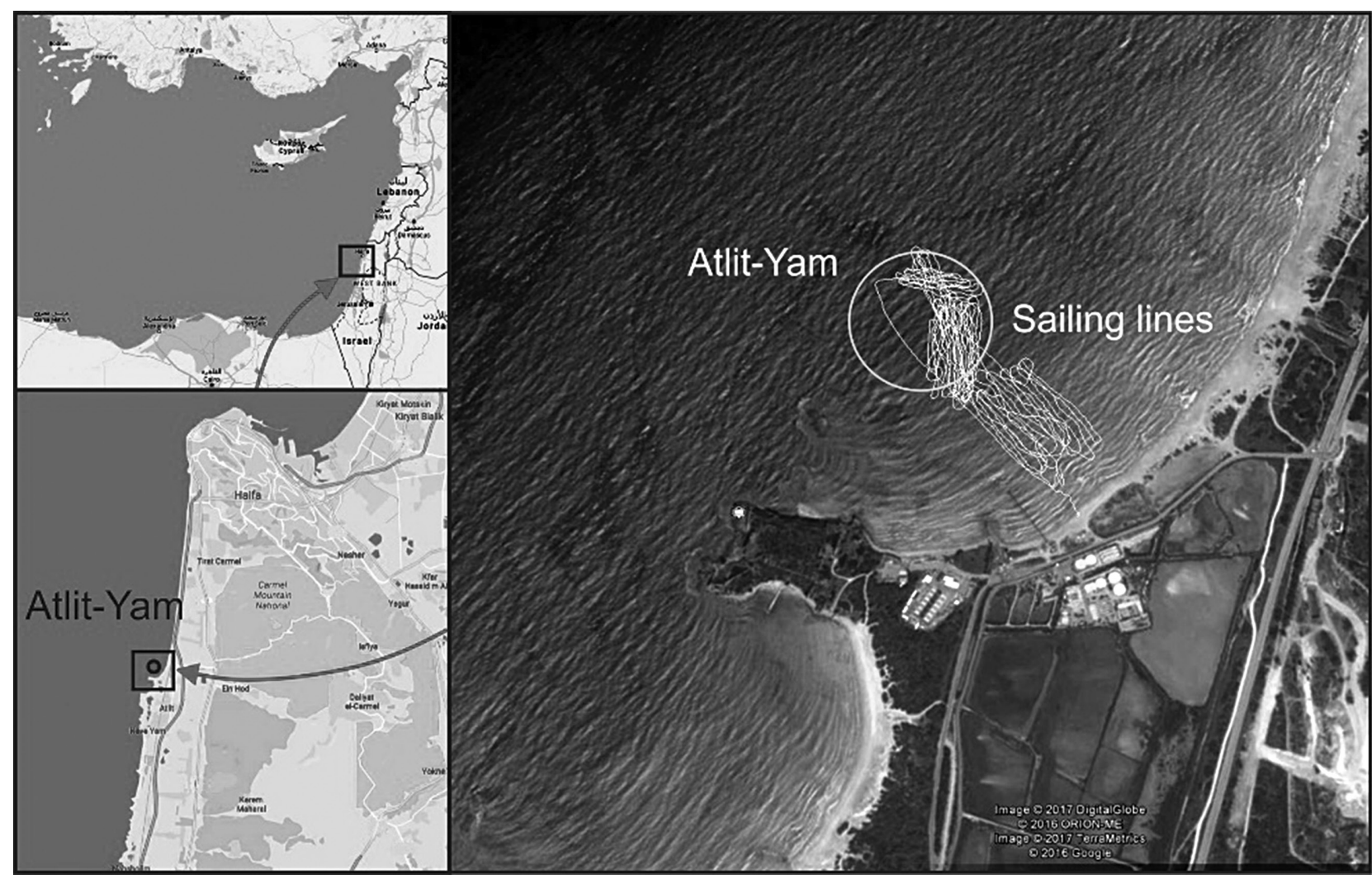

Fig 1: Left: Atlit-Yam, located 15 km SSE of Haifa (based on satellite images from Google Earth). Right: the coastline and the sailing lines. The circle marks the approximate outline of the Atlit-Yam Stone age settlement.

similar appearance has, however, proved difficult (Grøn and Boldreel, 2014). Surveys focusing on submerged Stone Age sites are today, therefore, mainly based on topographical/bathymetrical prediction (e.g. Fischer, 2004; Benjamin, 2010). The application of this approach to maritime archaeology in Denmark has been shown to detect less than $1 \%$ of the Stone Age sites that would be present in similarly surveyed areas on land: a figure that seems unreasonably low (Grøn, 2012, 2018; Gross et al., 2018). A more reliable way of identifying these settlements is therefore needed. A geophysical approach, such as the one discussed in this paper, could be used to outline target areas with much greater efficiency for inspection by divers or other verification methods.

In 2014, a collaboration was established between marine archaeologists from Norway and Israel and marine geophysicists from Denmark to test whether high-resolution seismic profiling could be applied successfully to the sandy, shallow sediments off the Israeli coast on a general basis as in Denmark (Boldreel et al., 2010), and specifically for the identification of sediment-embedded archaeological artefacts, as successfully as in Danish waters (Grøn et al., 2007; Grøn and Boldreel, 2014; Grøn et al., 2015). In 2014-15, field campaigns were carried out in the near-coastal parts of northern Israel to test whether high-resolution seismic profiling (Chirp III) could be used to identify shipwrecks, harbour constructions, settlements, including those from the Stone Age, and poles located in sandy sediments below the sea floor (Grøn et al., 2015; Cvikel et al., 2017). One of the sites investigated was the archaeologically well-documented Stone Age settlement of Atlit-Yam, located off Israel's Carmel coast (Fig 1), at a water depth of approximately 10-12 m.

In addition to large amounts of flint debitage ${ }^{+}$ (Figs $2 \mathrm{a}-\mathrm{c}$ ), the cultural remains recorded at AtlitYam include wall foundations, stone-built wells, burials and megaliths (Galili and Rosen, 2011) (see Fig $5 \mathrm{~b}$ in section 5.1). The site is dated to 7500-4600 cal BC, and it thereby represents the earliest known evidence for a 'agro-pastoral-marine subsistence' (Galili and Rosen, 2011). The large extent of the site is due, not least, to the fact that it was located on the coast and withdrew progressively in the face of rising sea levels (Galili and Rosen, 2011). Over the years, systematic recording and investigation have been undertaken for most of the $40000 \mathrm{~m}^{2}$ area of the site. These show that the remains are generally covered by $1 \mathrm{~m}-1.5 \mathrm{~m}$ of sand, although a

\footnotetext{
$\dagger$ The expression 'debitage' is used here to include all the pieces of flint removed from a core by knapping: blades, flakes and waste. It also includes tools produced on the basis of these, but excludes cores and core tools. This is because of clear evidence that pieces in the first category respond acoustically to certain frequency ranges, while this has not been observed for the latter.
} 


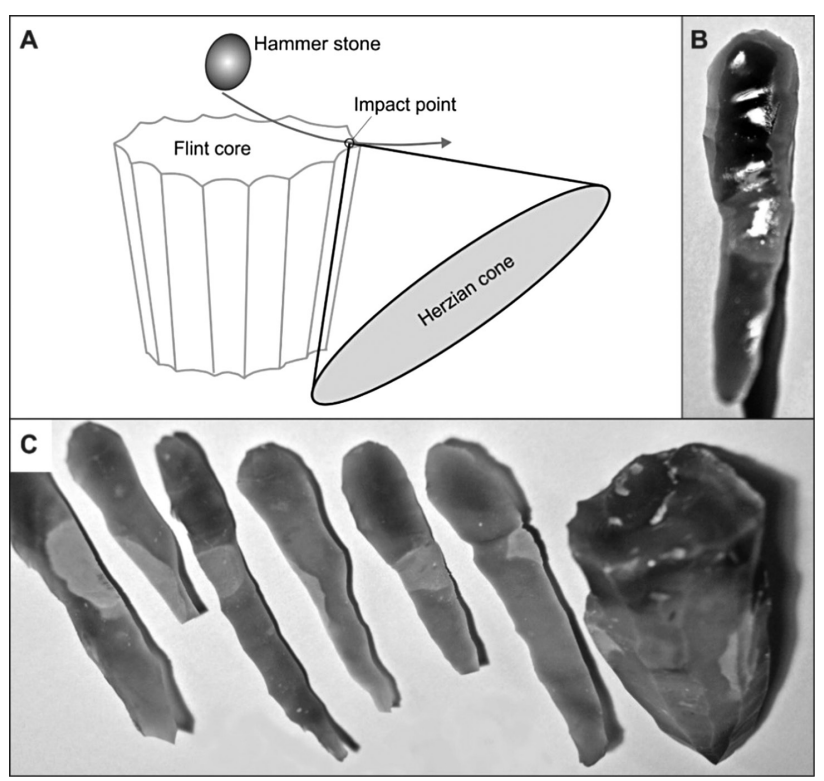

Fig 2: (a) Flint-knapping utilising the Hertzian cone phenomenon to remove long, sharp pieces of debitage (blades) from a prepared flint core. (b) A blade with the characteristic waves on its ventral side (inner surface in relation to the core). (c) Flint core with $5 \mathrm{~cm}-8 \mathrm{~cm}$ long, thin pieces of flint debitage (blades) removed.

small but variable part of the cultural deposits is generally exposed due to sediment dynamics (Galili and Rosen, 2011).

Seismic profiling had not been employed previously in the investigation of the Atlit-Yam settlement, and it was decided to test whether high-resolution seismic methods could provide new information about the site. The recorded data were of good quality and were analysed on a workstation using the computer software Petrel. Interpretation of the seismic profiles revealed that several of them displayed characteristic 'haystack-like' disturbances in the water column (Fig 3). Most of these were located in the parts of the investigated area where settlement remains from the Stone Age had been identified and were therefore related to the site's cultural layer, which contained significant amounts of human-knapped debitage. They were different from the employed equipment's signatures for sea-floor cavitation, vegetation, gas or salinity/temperature differences. They could resemble the signature of fish shoals but did not move over time. It was therefore suggested that the 'haystacks' observed at AtlitYam could be related to the human-knapped flint. This called for the first study of its kind, combining controlled field experiments, laboratory measurements and finite element modelling.

The aim of this paper is to underpin, on a broad methodological basis, the possibility of using acoustics to identify ancient Stone Age sites, based on their content of human-knapped flint debitage. This was achieved through the analysis of the spatial distribution of acoustic phenomena (haystack features) in relation to the recorded settlement features at Atlit-Yam, and the use of corroborating data from the Danish site of Møllegabet as well as data from two controlled seismic offshore experiments undertaken in Denmark. In the latter experiments, human-knapped flint debitage and flint cracked by geological processes was placed on the sea floor in bags and embedded in sediment in plastic buckets placed on the sea floor. It was then exposed to similar acoustic signals to those employed at Atlit-Yam

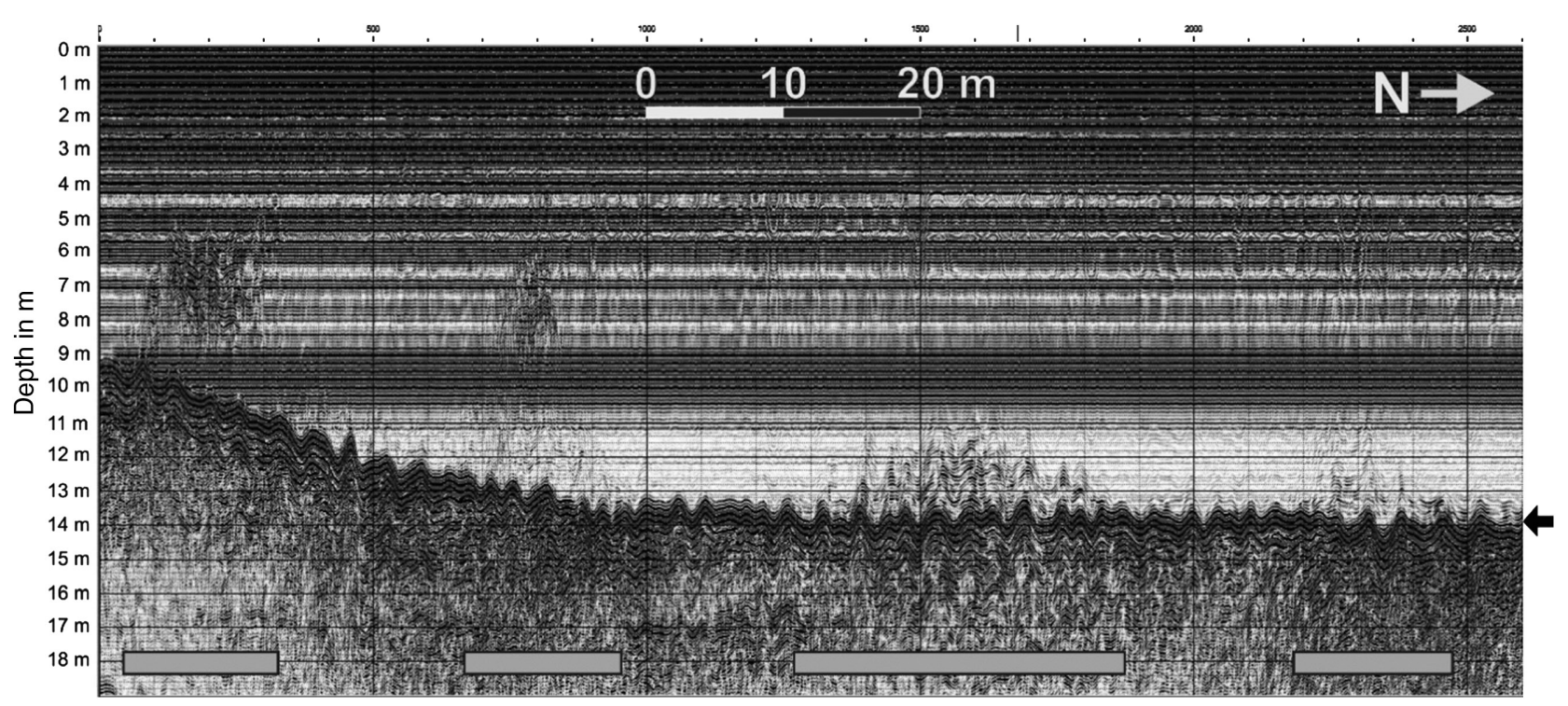

Fig 3: Four characteristic examples of haystack features in a part of profile 21 from Atlit-Yam (see Fig 5a). The grey bars at the bottom mark the horizontal extent of the haystack features. The black arrow to the right marks the sea floor, shown as a dark 'wavy' line below the haystacks. Horizontal noise bands can be seen in the water phase. 
to investigate whether an excited response could be detected. The results obtained from this research in Israel and Denmark correspond well to those obtained in sound laboratory experiments and from theoretical finite element modelling.

\section{Flint-knapping and the submerged Stone Age}

Flint is a hard, sedimentary cryptocrystalline form of the mineral quartz (Rykart, 1995). Owing to its widespread occurrence and good knapping properties, it played a central role as a raw material for the human production of sharp-edged artefacts during the 'Stone Age', dating back as far as Clark's 'Mode I Industry', 2.5 million years ago (Clark, 1977; Ambrose, 2001).

Flint-knapping technology (Fig 2) survived from the Stone Age to the 20th century in local technological niches, for example in the production of flint-spiked threshing sledges (Whittaker, 2014). Surviving flint-knapping has also been recorded in ethnographic contexts (e.g. Shackley, 2003). Consequently, it was still possible for prehistoric archaeologists to study a live flint-knapping tradition as a basis for modern experimental flint-knapping in the 20th century (Clarke, 1935).

Knapping flint involves the intentional removal, from a prepared core, of sharp pieces of debitage (Figs 2a-c). Subsequently, some pieces are shaped further (typically 'retouched') to make tools (Inizan et al., 1999). Our understanding of the flint-knapping process is that debitage (i.e. sharp pieces of flint) is removed from the edge of a prepared core as sections of 'Hertzian cones' (Fig 2). The shock waves that bring this about are created in a controlled way by the flint-knapper, for instance with a hammer stone (Fig 2a) (Inizan et al., 1999; Knapp, 2010).

Stone Age settlements located in now submerged areas of northern Europe have been shown to date from a period beginning almost 1 million years ago and extending up until the end of the Stone Age, about 4000 years ago. The high biomass production of marine coastal zones suggests that they would have been very attractive to humans, compared with other types of environment (Odum and Barrett, 2005; Grøn, 2015). Since extensive parts of the coastal zone, on the continental shelf extending down to $140 \mathrm{~m}$ below the present sea level, had potential for human settlement as related to the fluctuating sea level, they can be expected to have hosted relatively dense populations at various times in the past (Dix and Westley, 2006; Parfit et al., 2010; Bailey, 2011; Flemming et al., 2011; Tizzard et al., 2015).

The recovery from the sea floor of the southern North Sea of a large and diverse assemblage of remains of a so-called mammoth fauna dating from the Weichselian glaciation, and covering at least the time interval 45-30 ky BP, documents the potential value for humans of such open coastal areas (Glimmerveeen et al., 2004; Mol et al., 2006; Grøn, 2015; Moree and Sier, 2015). Many of the submerged Stone Age sites located in deeper waters today can be expected to have been damaged or totally reworked and redeposited due to marine currents and fluctuations in sea level (e.g. Dix and Westley, 2006). However, experience from the shallower and therefore more dynamic waters with strong currents occurring in sounds and straits, which cause disturbance and destruction, show that pockets with good conditions for preservation of such sites do exist, in some cases even with extremely good preservation of organic material (Skaarup and Grøn, 2004; Bendixen et al., 2017).

Where systematic surveys in Denmark have focused on mapping submerged Stone Age settlements, they have recorded a considerable number of potential sites. A good example of this is the pioneering approach adopted in 1972 by Langelands Museum. By 2004, these efforts had resulted in the recording of 126 such sites (Skaarup and Grøn, 2004). Even relatively vulnerable structures, such as graves containing skeletons, fish weirs and the remains of dwellings with stakes and, in one case, a bark-covered sleeping platform - have been found preserved under water using this strategy (Skaarup and Grøn, 2004; Uldum, 2011).

Systematic surveys with divers have their limits since they can mainly be used to record relatively shallow sites exposed on the sea floor and not the better protected ones embedded in sea-floor sediments.

To limit the survey area, surveys were, to some degree, directed by the 'fishing-site model' which has recently been shown to be rather ineffective for mapping Stone Age sites (Grøn, 2018; Gross et al., 2018).

The records are, in accordance with these limitations, strongly dominated by sites from the Late Mesolithic, whereas older and deeper sites are only rarely featured (Fischer, 2011). Therefore, the number of sites recorded today can only represent a fraction of the total, and locally their density will vary according to the level of effort invested in surveys for such sites.

\section{Acoustic detection of flint flake- and} blade-based tools and other debitage

During experimental flint-knapping, it was observed that the production of pieces of debitage produced a high, loud and characteristic tone as they were 


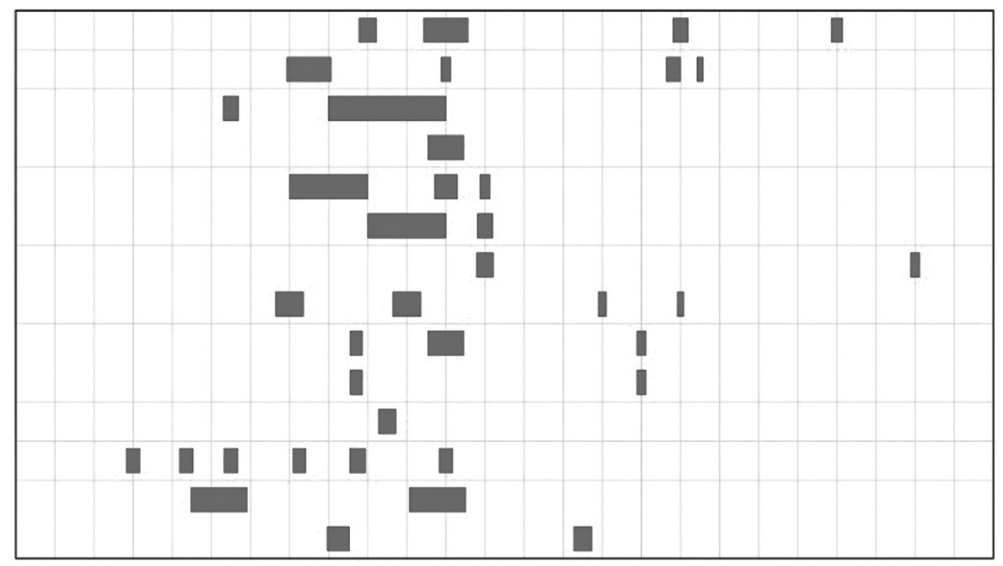

Site 9 , sample $1+2$

Site 6, sample $1+2$

Site 4 , sample 2

Site 4 , sample 1

Site 3, sample 2

Site 3, sample 1

Site 2, sample 2

Site 2, sample 1

Site 1, sample 2

Site 1 , sample 1

Svanemosen 28

Sliv Sø

Jels 1 - large piece

Jels 1 - small piece

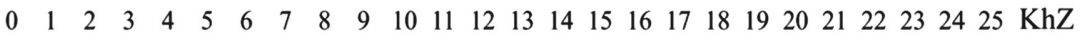

Fig 4: The frequency peaks measured for 16 pieces of flint debitage at the Bang \& Olufsen sound lab. The two upper samples each consist of two pieces of debitage (Rasmussen, 1982).

detached from the core. To test whether this phenomenon could be used for acoustic mapping of Stone Age sites, 16 pieces of human-knapped flint debitage (blades and flakes) (Fig 4), from nine geographically diverse sites in Denmark representing various Stone Age periods, were tested for resonance in the Bang \& Olufsen sound laboratory. All the pieces responded when excited with acoustic resonance in the interval $3-23 \mathrm{kHz}$, with the main area being 7-12 kHz (Fig 4). The pieces of debitage had to be damped during the tests so that the magnitude of their acoustic response did not damage the receiver. It was therefore concluded that it should be possible to detect flint debitage of this kind acoustically even when damped by being embedded in sediment.

To investigate whether it would be possible to detect the response from flint debitage embedded in sediments, finite element modelling of the response to various acoustic signals from a digital seafloor model was undertaken (Hermand et al., 2011; Hermand and Tayong, 2013). A high-resolution 3D digital model was constructed using minimal elements (finite elements) with physical characteristics ascribed to them that were identical to the materials they represented (Caiti et al., 2006). The 3D model consisted of thin layers of sand and mud overlying a till substrate. The model allowed humanknapped debitage pieces to be inserted and removed digitally without disturbing its sediment sequence (Hermand and Tayong, 2013).

The results corroborated the findings from the Bang \& Olufsen Sound Laboratory and showed that human-knapped flint debitage inserted into the model produced a different response to that without flint debitage, when exposed to identical emitted signals. This experiment confirmed that human-knapped flint debitage embedded in sediment responds acoustically to some types of acoustic signal with frequencies around $10 \mathrm{kHz}$, as observed in the Bang \& Olufsen sound laboratory. This reinforces the assumption that humanknapped flint can be detected acoustically when embedded in sediments (Hermand et al., 2011; Hermand and Tayong, 2013).

To test further the potential of acoustic resonance of flint, Chirp recordings were undertaken off Stevns Klint, Denmark, with a similar setup to that used at Atlit-Yam. Stevns Klint is a steep coastal chalk formation which, through erosion, has deposited large amounts of natural flint, including a significant fraction of flint cracked by geological processes, in the $10 \mathrm{~m}-15 \mathrm{~m}$ deep waters adjacent to it. From the boat used for the seismic recording, large patches of flint could be seen on the sea floor but no 'haystacks' were identified in the recorded seismic profiles. This strongly suggests that flint cracked by geological processes does not respond in the same way as human-knapped flint debitage. This therefore explains why the method appears to facilitate a focus on the latter category.

\section{Methodology}

\subsection{The Atlit-Yam recordings}

A small boat with an outboard motor was used for the recordings at the Atlit-Yam site. A single-beam Teledyne Chirp III sweeping the frequency interval $2 \mathrm{kHz}-20 \mathrm{kHz}$ was the acoustic source and system for recording. It consists of an emitter and a receiver mounted within the same instrument, directly beside each other on the $61 \mathrm{~cm}$ long recording platform (the fish). This facilitates precise recording of the positions of the dense recording points. The navigational offset is negligible, as no hydrophone cable is used with this method. The Chirp 
III instrument is generally well-suited for high-resolution recording of sediment-embedded archaeological features that may accompany areas containing human-knapped flint (Grøn and Boldreel, 2014; Cvikel et al., 2017).

The differential global positioning system (DGPS) was mounted in the middle of the Chip III fish, between the emitter and the receiver. C-Nav calibration of the navigation was used to obtain a precision of $\pm 10 \mathrm{~cm}$. The fish was mounted on the side of the boat to ensure that the recordings avoided disturbance from bubbles produced by the propeller, a serious potential problem for recording good data (Grøn and Boldreel, 2014). Apart from these elements, the acquisition setup was the same as described in Grøn and Boldreel (2014). Acquisition was undertaken at a speed of $\sim 1 \mathrm{kn}$ relative to the sea floor. Calm weather conditions are important for obtaining good results with highresolution recordings of archaeological features because this allows the instrument to be kept close to a specific reference level.

The recorded data were automatically processed in the Chirp's processor and saved in SEG-Y format, with the navigation being stored as UTM coordinates. Analysis of the recorded data was carried out on a workstation with Petrel software (other types of interpretation software can also be used). Despite some contamination by almost horizontal noise bands on the displayed seismic sections, high-resolution information was obtained from the water column, the sea floor and the sub-sea floor.

During the interpretation and mapping of features evident in the seismic data from the Atlit-Yam site, horizontally restricted acoustic disturbances (haystacks) in the seismic sections were present in the water column (see Fig 3). These cannot be ascribed to the almost horizontal noise bands. As a second step in the analysis, maps containing archaeological information from the research area were imported into the workstation and integrated into the interpretation process. This enabled the haystack features at the Atlit-Yam site to be correlated with the known archaeological features in the area.

\subsection{Two controlled high-resolution seismic experiments, Denmark}

Two controlled high-resolution seismic experiments were carried out in Denmark using the same Chirp III setup as at the Atlit-Yam site. The purpose of these experiments was to investigate further the acoustic characteristics of human-knapped flint debitage and flint pieces cracked naturally by thermal or geological processes.

Seismic profiles were acquired before the experiments were undertaken to ensure that the sites were free of disturbance in the water column, such as for instance 'haystacks'. In experiment 1, two $14 \mathrm{~kg}$ samples of flint were used. One sample consisted of various types of human-knapped flint debitage originating from the Stone Age and varied in size from less than $10 \mathrm{~mm}$ to more than $200 \mathrm{~mm}$, with a continuous distribution and with the main emphasis on the smaller pieces. The second sample consisted of a representative collection of various sizes of flint pieces cracked by thermal and geological processes (e.g. frost cracks, pressure cracks), which had been neither produced nor shaped by human knapping. The natural pieces were chosen for their resemblance to flint pieces knapped by humans.

A systematic comparison of the pieces in the two samples was not possible, because there is a much more elaborate morphological terminology for human-knapped flint debitage than for flint pieces cracked by thermal and geological processes. 'Blades' and 'flakes' were used as central categories for human-knapped flint debitage and the naturally cracked pieces included more than 300 'blade-like' and 'flake-like' pieces. These were evenly distributed within the size range $20 \mathrm{~mm}-140 \mathrm{~mm}$, with the main part being in the interval $20-50 \mathrm{~mm}$, as well as several larger irregular pieces matching the 'core pieces' in the human-knapped sample.

The two flint samples were placed separately in two cotton bags soaked in water to avoid the inclusion of air that could disturb the seismic signal. They were slowly lowered on to the sea floor at a water depth of $3.5 \mathrm{~m}$ from a small inflatable rubber dinghy that was also used for the recording, so as not to produce turbulence in the water column. The bags were placed $43 \mathrm{~m}$ apart on the sea floor to ensure that potential responses from them could be distinguished individually. They were left for $\sim 1 \mathrm{hr}$ to stabilise before recording commenced. In the test area, seismic profiles were acquired before commencing the experiment to ensure that there was no acoustic disturbance found in the water column in the seismic recordings. The recordings were made at a speed of $1 \mathrm{kn}$, crossing the positions of the bags and their surroundings numerous times.

In experiment 2, the $14 \mathrm{~kg}$ of human-knapped flint used in experiment 1 was buried in water-saturated sand in a plastic bucket and left for one month to ensure that no air bubbles were present. Before the bucket was lowered into the water, seismic profiles were recorded to ensure that there was no disturbance in the water column in the seismic profiles. The bucket was slowly lowered into the water and placed at a depth of $2.5 \mathrm{~m}$ on the sea floor and left for some time to allow the water column to stabilise. After this, numerous high-resolution profiles were acquired that crossed over the bucket and its surrounding areas. 


\section{Results}

\subsection{Recordings from Atlit-Yam, Israel}

Fifty-nine high-resolution seismic profiles were recorded at Atlit-Yam (Fig 1) at a water depth of $10 \mathrm{~m}-12 \mathrm{~m}$, with the sandy sea floor sloping slightly downwards out from the coast and to the north into the investigated area. Conditions were calm with only minor swells during the experimental survey and with clear visibility in the sea. For the recording, the surveyed area was subdivided into three parts: a northern (I), a central (II) and a southern (III) area. Area II is shown in Fig 5a, areas I, II, III in Fig 5b. In the central area (II), remains from the settlement have been previously recorded through marine archaeological fieldwork, whereas only a few similar remains have been recorded in the northern area (I), and none in the southern area (III) (Galili and Rosen, 2011) (Fig 5b).

Of the 13 profiles orientated east to west through the northern area (I), four show haystack features (0.31 per recorded profile). Of the 30 profiles acquired in the central area (II), haystack features are evident in 28 profiles as 57 separate observable haystack features (1.90 per recorded profile). Of the 21 profiles cutting through the southern area (III), only one profile shows a single haystack feature.

The haystack features are widest at their base, nearest the sea floor, and become narrower, culminating in a peak or a rounded plateau well before they reach the sea surface. Some variation can be observed in their height and width (Fig 3). The phenomenon is particularly evident in the central part of area II, where the archaeological features are concentrated, in adjacent and crossing profiles (Fig 5) acquired at different times of the day. In area II, a concentration of haystack features is noted just around the position where a flint workshop was excavated, which contained a higher concentration of human-knapped flint debitage than was observed in the other parts of the cultural layer (Fig 5b) (Galili and Rosen, 2011). This dense zone of significant haystack features extends from the area around the flint workshop and $50 \mathrm{~m}$ to the north-northeast. Fig 5 a shows that the locations of the haystacks are grouped within several smaller zones, as well as the large zone associated with the flint workshop. Within the part of the site covered by sailing lines, the haystack features coincide consistently with the extent of the site's archaeological remains as recorded through several years of archaeological fieldwork, even though the main part of the cultural layer to which they are related is covered by up to $1.5 \mathrm{~m}$ of sand.

The haystack features appear consistently as horizontally restricted phenomena in permanent positions in the straight parts of the sailing lines. They cannot therefore be ascribed to the turning of the vessel at the end of the crossings or to the presence

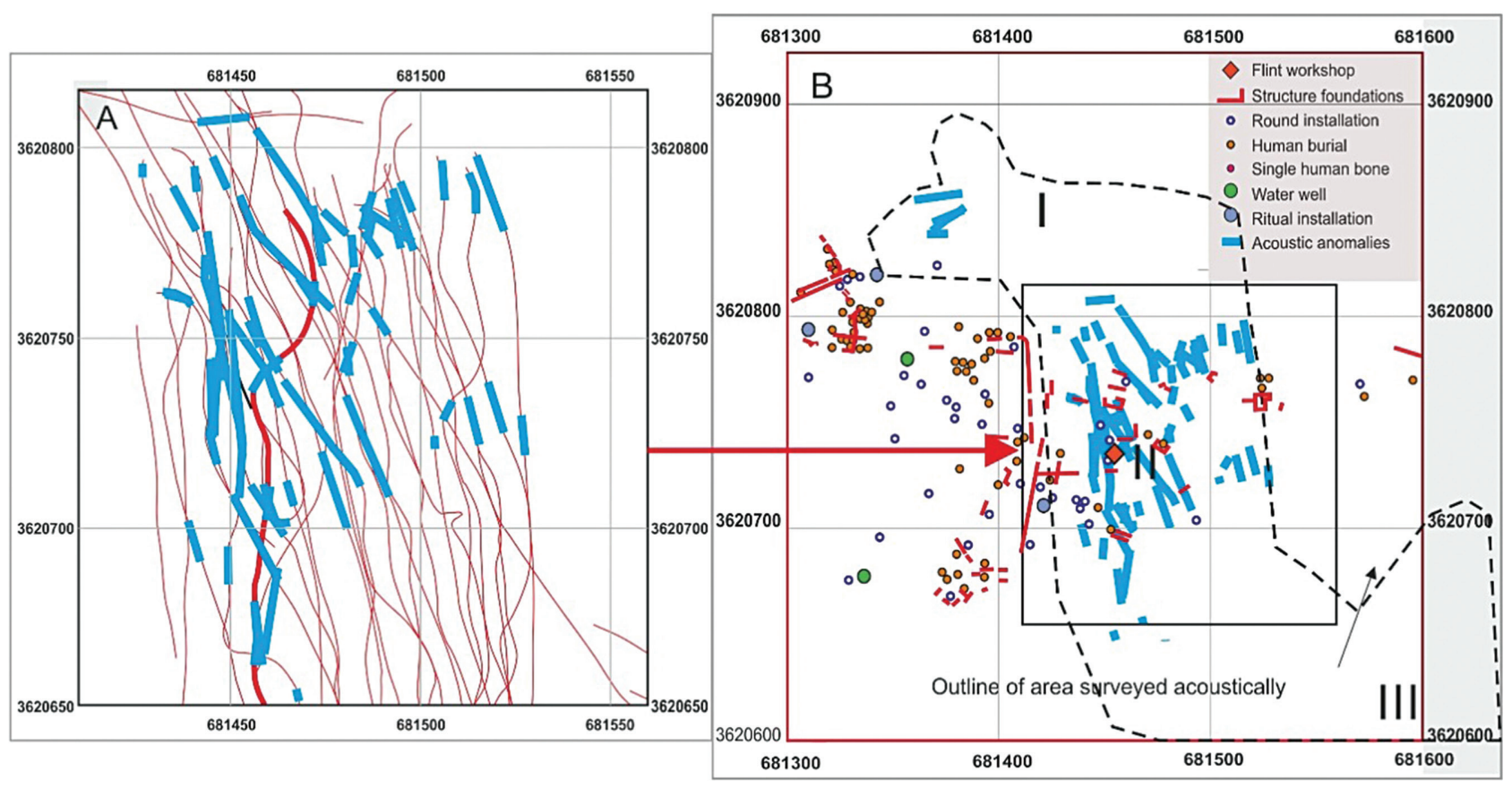

Fig 5: (a) The sailing lines recorded in area II Atlit-Yam. Profile 21 (see Fig 3) is shown as a thick red line. The blue line fragments mark locations where haystacks were observed in the profiles. (b) The surveyed part of the settlement area is marked with a broken black line. Coordinates are in Universal Transverse Mercator (UTM) zone 36N. 
of schools of fish. The slow speed of $1 \mathrm{kn}$ ensured that they were not caused by turbulence/bubbles from the outboard motor.

The fact that the tops of the haystack features are well below the sea surface, and that no air bubbles were observed coming up from the sea floor, shows that the haystack phenomena are not caused by gas leaking from the subsea floor into the water column. Furthermore, no signs of shallow gas accumulation are evident on the seismic profiles.

The haystacks do not mimic the sea-floor bathymetry (see Fig 3 in section 1), which would have been the case if these phenomena had been related to the morphology of the seabed. There was no seafloor vegetation in the study area, so this cannot be the reason for the observed anomalies. No indications were observed, or could be hypothesised, which could explain the observed anomalies as reflecting salinity/temperature differences.

A clear spatial correlation can therefore be observed between the haystack features and the settlement's cultural layer with physical structures and containing significant amounts of human-knapped flint debitage (detailed in the discussion below). It has been demonstrated experimentally that this type of feature (i.e. haystack) is related to humanknapped flint debitage, even when embedded in sediments, but not to naturally cracked flint. Furthermore, it has been demonstrated in the Bang \& Olufsen sound laboratory that human-knapped flint debitage displays a strong resonance feature (see Fig 4 in section 3 ) around $10 \mathrm{kHz}$. In addition, finite element modelling underpins the Bang \& Olufsen lab results (Hermand et al., 2011; Hermand and Tayong, 2013). It can therefore be concluded that the haystacks observed at Atlit-Yam are most likely related to the human-knapped flint debitage occurring in the site's cultural layer, and should most probably be interpreted as an acoustic response from this.

\subsection{Results of two controlled experiments, Denmark}

The two Danish experiments outlined in section 4.2 were carried out to test whether the occurrence of human-knapped flint debitage located on the sea floor or embedded within its sediments can produce haystack features like those observed in the recorded seismic profiles at Atlit-Yam. The results of the seismic recordings are shown in Fig 6.

A1-A3 in Fig 6 show three seismic profiles crossing the bag containing naturally cracked pieces, and B1-B3 show three seismic profiles crossing the bag containing human-knapped pieces. In all six profiles, the bags are visible on the sea floor, thereby demonstrating that these seismic recordings transect the target bags. In the water column directly above the bag with human-knapped flint debitage, all three profiles display disturbances like the haystack features observed at Atlit-Yam (Fig 6b), whereas the bag containing naturally cracked flint pieces does not produce a similar disturbance in the water column (Fig 6).

C1-C3 shows the results for experiment 2, where the three profiles transect the sample of humanknapped flint debitage used in experiment 1 , now buried in a plastic bucket filled with water-saturated sand. Disturbances similar to the haystack features evident at Atlit-Yam can be observed directly above the bucket, which is also visible on the sea floor in the recordings.

\subsection{Results from Møllegabet, Denmark}

A submerged Mesolithic settlement, Møllegabet, in the southern part of Denmark, was excavated in the period 1976-93. The settlement dates from the Early and Middle Ertebølle culture and was related to different palaeo-coastlines, representing the rising sea level from around 5250-4400 cal. BC (Skaarup and Grøn, 2004). The deeper part of the settlement yielded a boat grave containing the skeletal remains of a male and remains of a dwelling with its still partly bark-covered platform preserved (Skaarup and Grøn, 2004). In the eastern part of the settlement, at a water depth around $2.5 \mathrm{~m}$ below present sea level, there was an $75 \mathrm{~cm}$ thick kitchen midden, which accumulated as a result of Late Mesolithic hunter-gatherers' habitation adjacent to the $4400 \mathrm{cal}$ BC coastline.

Human-knapped flint was abundant at the site but was removed during the excavations from the limited areas excavated in the kitchen midden and to the offshore side of it, as well as in and around the boat grave and the dwelling, which were both excavated in full (Skaarup, 1995; Skaarup and Grøn, 2004). A few high-resolution seismic profiles across the site were acquired in 1996, using a Datasonics Chirp II instrument very similar to the Chirp III instrument (Skaarup and Grøn, 2004).

In the light of the results obtained at Atlit-Yam, and in the controlled seismic experiments, the profiles from Møllegabet were re-examined for this study to determine whether similar acoustic disturbances were present within the water column. The recording instrument was, however, an older version than that used at Atlit-Yam and in the Danish experiments, and lacked some of the later improvements. On the seismic profile cutting through the shell midden, two clear acoustic responses in the water phase can be observed from the central part of the kitchen midden's northern half, which was not excavated prior to the recording (Fig $7 \mathrm{a}$ ). It is 
Vertical scale on Figs a-c is in milliseconds two-way travel time (the integer 1 corresponds to $0.75 \mathrm{~cm}$ water depth)

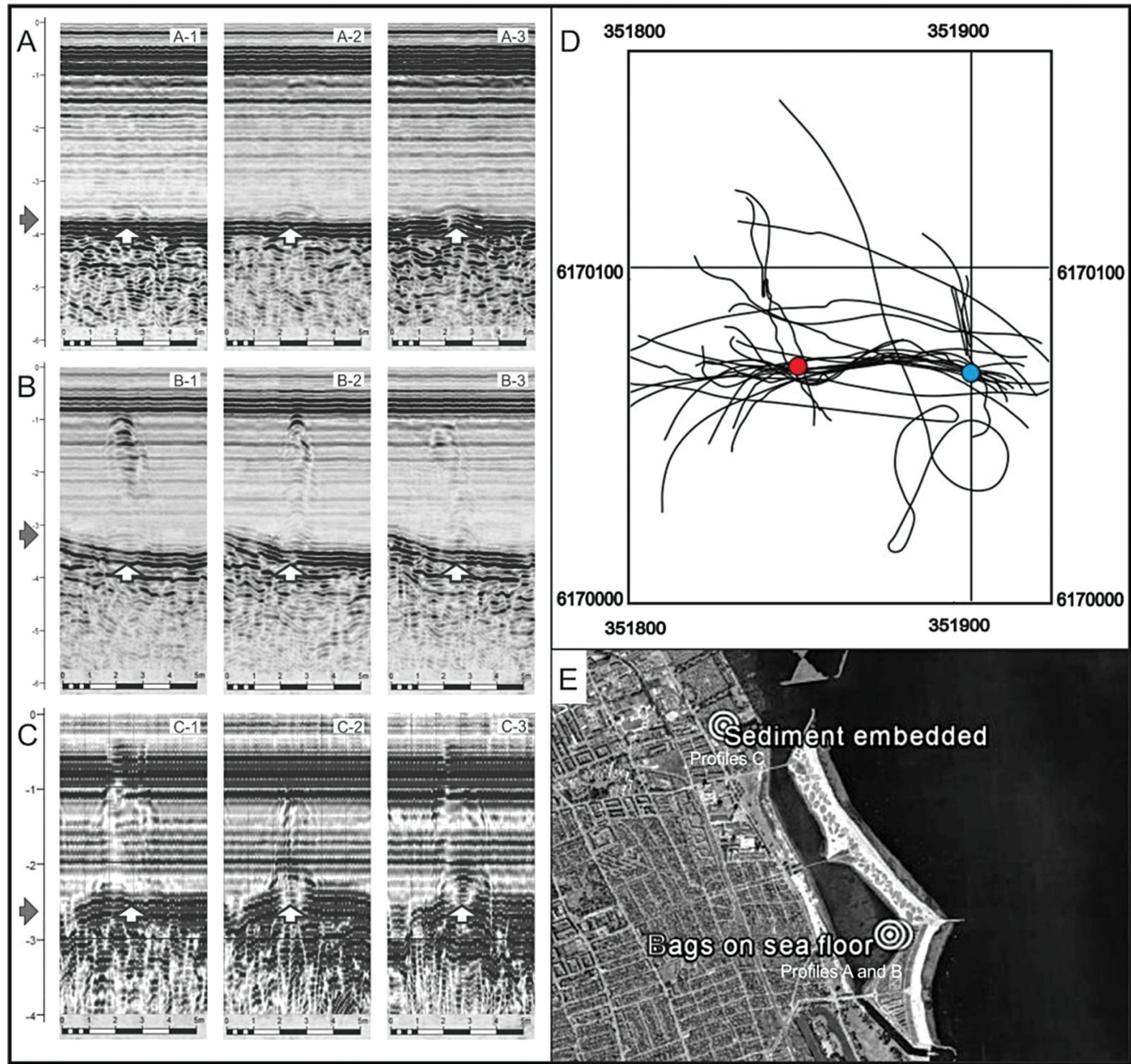

Fig 6: (A-C) Seismic profiles recorded during the experiments. Grey arrows indicate the level of the sea floor. The bags/bucket with flints are marked with white arrows and can be discerned on the sea floor. (A1-A3) Experiment 1: naturally cracked flint in a bag. No flint response is evident in the water column. (B1-B3) Experiment 1: human knapped flint in a bag. A clear acoustic flint response can be observed in the water column. (C1-C3) Experiment 2: human knapped flint in sediment filled bucket. A clear acoustic flint response is evident in the water column. (D) The sailing lines for experiment 1. The blue dot represents the bag containing human-knapped flint debitage and the red dot represents naturally cracked flint. (E) Experiment 1 in the southern part of the lagoon of Amager Strandpark. Experiment 2 in the little harbour of Sundby Sailing Union north of the lagoon.

known from repeated diving activity in the area that these responses do not represent physical structures, air-filled seaweed or gas leaking from the sea floor.

\section{Discussion}

The high-resolution seismic profiles obtained from Atlit-Yam, the profiles from the Møllegabet site and the controlled seismic experiments in Denmark revealed systematically occurring acoustic disturbances, so-called haystack features, in the water column. These features are found directly above areas containing human-knapped flint debitage and do not reflect sea-floor cavitation, vegetation, fish shoals, gas or temperature/salinity differences.

In the many seismic profiles acquired from the central part of the Atlit-Yam site (zone II), the haystacks occurred most frequently and with the highest density at locations characterised by the presence of prehistoric structures and a cultural layer containing human-knapped flint debitage. The intersecting profiles recorded here display a number of zones consistently producing haystack features, regardless of the varying time of recording through the day. In the northern part of the recording area 


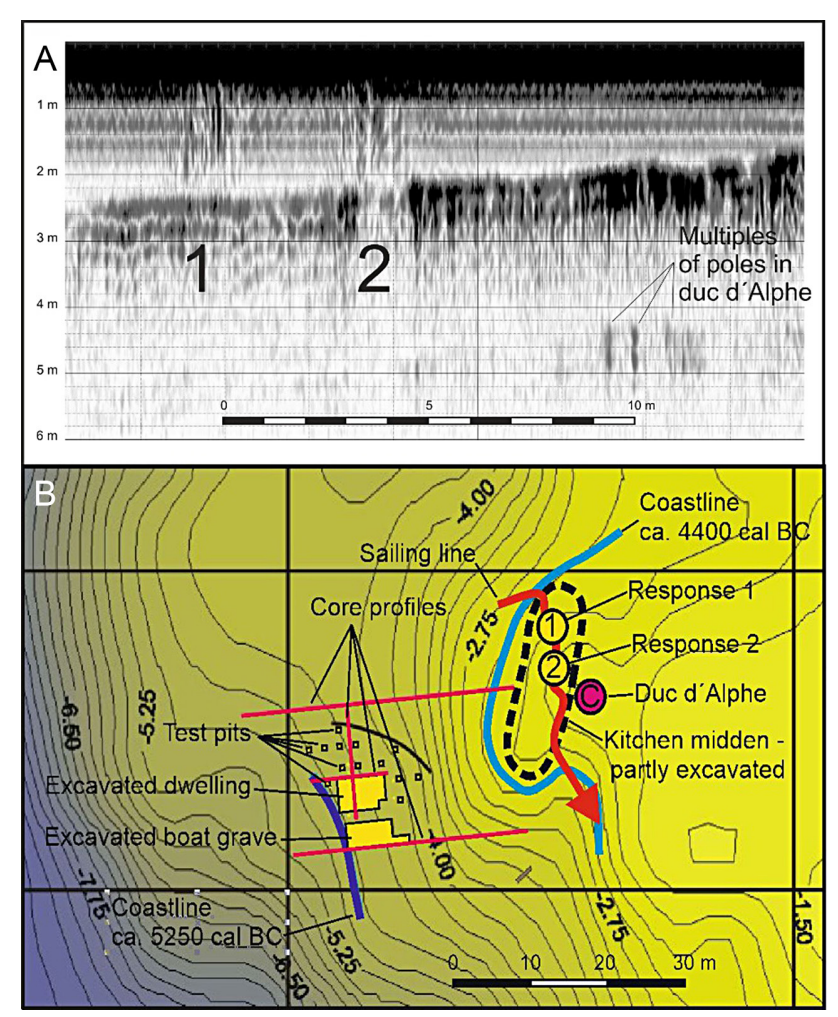

Fig 7: Submerged Stone Age settlement Møllegabet, Denmark. (a) the profile cutting north to south through the kitchen midden at Møllegabet with two haystack features, 1 and 2. (b) Bathymetric plan over the excavated archaeological features and the coastlines they date (Skaarup and Grøn, 2004).

(zone I), similar features were evident in four profiles, apparently signifying one coherent haystack zone. Only one haystack feature was observed in the south-eastern zone III (see Fig 5).

The height, width and general magnitude of the haystacks show some variation but can be generalised as being widest near the sea floor and their top below (i.e. not touching) the surface of the water phase. Their horizontal stability at Atlit-Yam means they cannot be explained as reflections of biological phenomena. The fact that they do not reach the surface of the water column strongly indicates that the haystacks cannot be explained as gas/bubble phenomena. It is also clear that they are not related to the sea floor morphology (see Fig 3).

Their distribution coincides closely with the location of the preserved settlement features and the cultural layer containing human-knapped flint debitage (Fig 5b). It is normal at Stone Age settlements that human-knapped flint debitage appears in several smaller concentrations. These can be interpreted as smaller activity/living areas, which form part of the settlement's overall spatio-chronological activity configuration (e.g. Grøn, 2003; Grøn and Kuznetsov, 2004). The four responses obtained from the northern area (zone I), which apparently reflect only one haystack zone, and the single small haystack feature recorded from the southern area (zone III) at Atlit-Yam, are both interpreted as small occurrences of human-knapped flint debitage that have not, as yet, been recorded by archaeologists.

At the Danish settlement of Møllegabet, earlier Chirp II data were re-interpreted and revealed haystack features over the kitchen midden containing flint debitage similar to those observed at Atlit-Yam (Skaarup and Grøn, 2004).

The experimental testing in Denmark was carried out with identical instrumentation and acquisition parameters to those employed at Atlit-Yam. This demonstrated the repeatability of the phenomenon and the relationship between the occurrence of human-knapped flint debitage and haystack features, both with flint debitage exposed on the surface of the sea floor and when covered by $1 \mathrm{~m}-1.5 \mathrm{~m}$ of sea-floor sediments, as at Atlit-Yam.

The control experiment involving a $14 \mathrm{~kg}$ sample of naturally cracked flint produced no acoustic response. Based on these experiments, it is concluded that the haystack features observed at Atlit-Yam represent acoustic responses from the site's large quantities of human-knapped flint debitage, most of which are covered by up to $1.5 \mathrm{~m}$ of sea-floor sediments. It is suggested that the haystack features occur because the debitage is excited by the highfrequency seismic signals emitted by the acoustic system. This conclusion was further corroborated by seismic recordings and excavation findings from Møllegabet, Denmark; the results of 3D finite element modelling of human-knapped flint debitage embedded in sea-floor sediments (Hermand et al., 2011; Hermand and Tayong, 2013); and measurements of human-knapped flint debitage in the Bang \& Olufsen sound laboratory. It seems that strong, measurable resonance is excited in the flint debitage by the high-frequency signal emitted by the Chirp III. The fact that the haystacks are evident in the water phase, and therefore appear to be recorded before the first signal reflection from the sea floor, could well reflect a signal delay.

The shapes of the haystacks on the Atlit-Yam seismic profiles show variation in their extent, form and height (Fig 3). It is presently uncertain what causes this variation, but it is speculated that it may reflect differences in the amount of flint debitage excited, the size of the debitage pieces and their orientation in relation to the acoustic signal. These aspects are, however, beyond the scope of this preliminary empirically based discussion. The ongoing method development and investigation of the physical principle behind it will hopefully provide a good theoretical understanding of the phenomenon and facilitate optimal application of it. 
The apparent consequence of this previously unreported acoustic phenomenon is that it appears possible to generate resonance in human-knapped flint debitage when excited with the appropriate frequencies. It has been demonstrated that it is possible to identify and map areas characterised by the occurrence of human-knapped flint debitage on the sea floor or embedded at least $1.5 \mathrm{~m}$ into the sea-floor sediments. Not only that, but it can be done with an affordable basic technical setup such as a Teledyne Chirp III sweeping the critical frequency interval of $2-20 \mathrm{kHz}$, and a precise navigation unit, combined with expertise and experience. Flint cracked by thermal or geological processes produced no similar acoustic response when subjected to the same signals and frequencies. Haystack features were also not observed in recordings made offshore from Stevns Klint, Denmark, where there is an abundance of flint cracked by thermal and geological processes on the sea floor. An important implication of these findings is that haystack features, such as those discussed here, appear to serve as indicators of human activity.

The present state of the technology represents a significant advance in relation to the hitherto employed methods for mapping submerged Stone Age sites embedded in sediments, even though the sensitivity of the method discussed here is still undergoing improvement. Deep towing of the Chirp III fish also allows efficient mapping and/or verification of sites that are not accessible by divers. The method can therefore already be used in its present state to improve the detection rate for submerged Stone Age settlements. With current use of topographical/ bathymetric predictive modelling, the detection rate appears to be around, or even less than, $1 \%$ of the total number of the Stone Age sites present. Given sufficient signal development on application of the acoustic method, it should theoretically be possible to raise detection to an estimated $50 \%$ of the submerged sites containing human-knapped flint debitage in the areas subject to direct survey, and perhaps even higher (Fischer, 2004; Benjamin, 2012; Grøn, 2012, 2018).

A further corollary of the method presented here will be facilitation of a considerable improvement in the mapping and dating of the fluctuations evident in submerged prehistoric coastlines, because in the Stone Age, coasts represented the most attractive environments for exploitation and settlement by humans (Odum and Barrett, 2005). There has been increasing recognition of this by archaeologists in recent years, even though these coastal sites often lie submerged today and are therefore difficult to locate and study (Schackleton and van Andel, 1986; Parfitt et al., 2005; Richards et al., 2005;
Jaksland, 2008, 2009; Bjerck, 2009; Wikell et al., 2009; Parfitt et al., 2010; Cortés-Sánchez et al., 2011; Ramos et al., 2011; Cuenca-Solana et al., 2013; Fischer et al., 2013).

Submerged prehistoric coastal settlements with good preservation of organic material can facilitate a more precise dating of the coastline than is possible using purely geological features. This is because, in some cases, it will be possible to obtain samples for dating (radiocarbon, etc.) from human structures positioned only a few metres from the contemporaneous coastline. It will also be possible to distinguish overlapping cultural deposits, representing short time intervals, that can be used to obtain 'sharpened' radiocarbon dating through wiggle-matching (Van Geel and Mook, 1989). This presents the opportunity of obtaining much more detailed dating of the sediments, thereby providing high-quality input for the mapping of sea-level variation and an understanding of geological evolution.

Stone Age settlements should not only be understood as habitation areas for prehistoric humans, but also as dumps for the remains of the organisms (animals and plants) they extracted from their immediate environment for food, clothes, etc. (e.g. Wilmsen, 1973; Sahlins, 1974; Service, 1979; Binford, 1980). Good examples of this are the enormous shell middens, the accumulated shells of consumed molluscs, together with other food remains, which formed in some places (e.g. Muller et al., 2002; Jerardino, 2010; Balbo et al., 2011). Common features of such sites are so-called waste/refuse layers, directly associated with the living areas and containing discarded organic materials such as mammal, bird and fish bones, as well as the remains of acorns, hazelnuts and other nuts, fruits and berries. The waste was often deposited in water, probably to reduce the stink of decomposing organic material (e.g. Rust, 1937; Balbo et al., 2011; Conneller et al., 2012; Andersen, 2013). Such accumulations would generally lead to the formation at the settlements of significant concentrations of animal and plant DNA derived from the immediate environment, relative to the general level of ancient DNA in the landscape.

It is possible to retrieve ancient animal and plant DNA directly from sediments with good DNA preservation, for example permafrost (Willerslev et al., 2004). Leaching out of the ancient DNA appears not to be a problem in permafrost sediments and sediments that have recently thawed (Willerslev et al., 2014).

Ancient DNA from non-frozen sediments also appears to be a rich potential source of environmental information, given that it is recovered from an uncompromised stratigraphic sequence. As the 
DNA fragments themselves are negatively electrically charged, they bind to the positively charged sediment particles and generally only leach out when the latter become displaced (Romanowski et al., 1991; Lorenz and Wackernagel, 1992; Haile et al., 2007; Lalonde et al., 2012; Rawlence et al., 2014). The risk of such disturbance should be less in buried and water-saturated sea-floor sediments than in terrestrial sediments, which have a dynamic exchange between water/ground water and air. Consequently, the possibility of obtaining undisturbed ancient DNA samples from cultural deposits at submerged Stone Age sites should generally be better than on land. As saline environments, such as saltwater-saturated sediments, appear to preserve ancient DNA surprisingly well (Corialdesi et al., 2011; Coolen et al., 2013; Lejzerowicz et al., 2013; Smith et al., 2015), this means that the potential for studying prehistoric environmental processes through ancient DNA accumulated and preserved in settlement-related sediments under water is significantly better than for non-frozen sediments on land.

Acoustic mapping of Stone Age sites, is of further interest to archaeology because the positions of these settlements can reflect human dispersal routes and man-nature interaction in prehistory. They therefore provide access to a huge body of hitherto unrealised data for an understanding of sea-level change and for reconstruction of the related environmental processes.

In relation to the construction of offshore installations and the extraction of raw materials from the sea floor, the importance of protection and management of submerged Stone Age sites, in both national and international waters, is promoted by the 2001 UNESCO Convention on the Protection of the Underwater Cultural Heritage (UNESCO, 2001). For proper practical management of such submerged Stone Age sites, it is important to develop more efficient mapping methods than the bathymetrically/ topographically-based predictive modelling methods currently practised today. Scanning of the potential impact areas with a direct detection-centred method prior to any detailed planning would be a methodologically and economically sensible strategy.

\section{Conclusions}

In high-resolution (Chirp III) reflection seismic profiles recorded at the submerged Stone Age site of Atlit-Yam, Israel, acoustic disturbances in the water column resembling haystacks were observed. These show a pronounced correlation with the location of the large amounts of human-knapped flint debitage present in the cultural layer of this submerged Stone Age settlement.
Earlier recordings from the submerged Møllegabet site in Denmark, reanalysed during this study, show similar disturbances in the water column. In Møllegabet, archaeological investigations undertaken prior to the recordings show a correspondence between haystack features and the occurrence of flint debitage.

Controlled Chirp III seismic experiments, employing similar acquisition parameters to those used for the recordings at Atlit-Yam, show that a test sample of human-knapped flint debitage located on the sea floor, or embedded within its sediments, produces a similar response to those observed at Atlit-Yam when acoustically excited. Flint cracked by thermal and geological processes was tested in the same experimental setup, with the same acquisition parameters, and displayed no similar response in the water column.

Laboratory-based measurements of the resonance of human-knapped flint debitage shows an acoustic response in the frequency area around $10 \mathrm{kHz}$, even though the flint pieces are damped. 3D finite element modelling confirms that acoustic responses can be recorded from such sediment-embedded pieces of flint.

It is therefore concluded that human-knapped flint debitage on the sea floor, as well as that embedded within its sediments, can be brought to resonance by certain acoustic signal types emitted by a high-resolution seismic system, and that this consequent acoustic response can be recorded.

The experimental application of high-frequency seismic equipment instruments constitutes a new way of detecting and mapping human-knapped flint and thereby of mapping the presence of submerged Stone Age settlements.

\section{Acknowledgments}

The survey at Atlit-Yam (IAA permit S-688/2016) was supported by the Israel Science Foundation (grant no. 1899/12) and conducted with the assistance of Amir Yurman and Moshe Bachar from the maritime workshop of the Leon Recanati Institute for Maritime Studies, Haifa; and Peer T. Jørgensen, Department of Geosciences and Natural Resource Management, Copenhagen, who served as a technician. Thanks to Schlumberger for the Petrel university grant issued to the Department of Geosciences and Natural Resource Management, Geology Group, University of Copenhagen.

\section{References}

Ambrose SH. (2001). Paleolithic Technology and Human Evolution. Science 291: 1748-1753. 
Andersen SH. (2013). Tybrind Vig. Submerged Mesolithic settlements in Denmark. Jutland Archaeological Society Publications Vol. 77. Moesgaard Museum, 527 pp.

Bailey GN. (2011). Continental Shelf Archaeology: where next? In: Benjamin J, Bonsall C, Pickard C and Fischer A. (eds.) Submerged Prehistory. Oxford: Oxbow Books, 311-328.

Balbo AL, Madella M, Godino IB and Álvarez M. (2011). Shell midden research: An interdisciplinary agenda for the Quaternary and Social Sciences. Quaternary International 239: 1-6.

Bates RC, Lawrence M and Dean M. (2011). Geophysical methods for wreck-site monitoring: the rapid archaeological site surveying and evaluation (RASSE) programme. The International Journal of Nautical Archaeology 40: 404-416.

Bendixen C, Jensen JB, Boldreel LO, Clausen OR, Bennike O, Seidenkrantz M-S, Nyberg J and Hübscher C. (2017). The Holocene Great Belt connection to the southern Kattegat, Scandinavia: Ancylus Lake drainage and Early Littorina Sea transgression. Boreas 46: 53-68.

Benjamin J. (2010). Submerged Prehistoric Landscapes and Underwater Site Discovery: Reevaluating the 'Danish Model' for International Practice. Journal of Island $\mathcal{E}$ ? Coastal Archaeology 5: 253-270.

Binford LR. (1980). Willow smoke and dogs' tails: huntergatherer settlement systems and archaeological site formation. American Antiquity 45: 4-20.

Bjerck HB. (2009). Colonising seascapes: comparative perspectives on the development of maritime relations in the Pleistocene/Holocene transition in north-west Europe. In: McCartan S, Schulting R, Warren G and Woodman P. (eds.). Mesolithic Horizons. Oxford: Oxbow Books, 16-23.

Boldreel LO, Grøn O, Galili E and Cvikel D. (2018). 3D documentation of shipwrecks embedded in sea-floor sediments. In: Proceedings of the 2017 IEEE/OES Acoustics in Underwater Geosciences Symposium (RIO Acoustics), 25-17 July, Rio de Janeiro, Brazil.

Boldreel LO, Kuijpers A, Madsen EB, Hass C, Lindhorst S, Rasmussen R, Nielsen MG, Bartholdy J and Pedersen JBT. (2010). Postglacial sedimentary regime around northern Sylt, South-eastern North Sea, based on shallow seismic profiles. Bulletin of the Geological Society of Denmark 58: 15-27.

Caiti A, Chapman NR, Hermand J-P and Jesus SM. (2006). Acoustic sensing techniques for the shallow water environment: Inversion methods and experiments. Netherlands: Springer Science and Business Media, 332 pp.

Clark G. (1977). World Prehistory in New Perspective, third edition. Cambridge: Cambridge University Press, $576 \mathrm{pp}$.

Clarke R. (1935). The flint-knapping industry at Brandon. Antiquity 9: 38-56.

Coolen MJ, Orsi WD, Balkema C, Quince C, Harris K, Sylva SP, Filopova-Marinova M and Giosan L. (2013). Evolution of the plankton palaeome in the Black Sea from the Deglacial to Anthropocene. Proceedings of the National Academy of Sciences 110: 8609-8614.

Conneller C, Nilner N, Taylor B and Taylor M. (2012). Substantial settlement in the European Early Mesolithic: new research at Star Carr. Antiquity 86: 1004-1020.

Corinaldesi C, Barucca M, Luna GM and Dell'Anno A. (2011). Preservation, origin and genetic imprint of extracellular DNA in permanently anoxic deep-sea sediments. Molecular Ecology 20: 642-654.

Cortés-Sánchez M, Morales-Muñiz A, Simón-Vallejo MD, Lozano-Francisco MC, Vera-Peláez JL, Finlayson C, Rodríguez-Vidal J, Delgado-Huertas A, Jiménez-Espejo FJ, Martínez-Ruiz F, Martínez-Aguirre MA, Pascual-Granged
AJ, Bergadà-Zapata MM, Gibaja-Bao JF, Riquelme-Cantal JA, López-Sáez JA, Rodrigo-Gámiz M, Sakai S, Sugisaki S, Finlayson G, Fa DA and Bicho NF. (2011). Earliest known use of marine resources by Neanderthals. PLoS one 6: e24026, 15 pp.

Cuenca-Solana D, Gutiérrez-Zugasti I, Gonzalez-Morales MR and Clemente-Conte I. (2013). Shell technology, rock art, and the role of marine resources during the Upper Palaeolithic. Current Anthropology 54: 370-380.

Cvikel D, Grøn O and Boldreel LO. (2017). Detecting the Ma'agan Mikhael B shipwreck. Underwater Technology 34: 93-98.

Dix J and Westley K. (2006). Archaeology of continental shelves: a submerged pre-history. In: Newell RC and Garner DJ. (eds.) Marine aggregate dredging: helping to determine good practice. Proceedings of the Marine Aggregate Levy Sustainability Fund (ALSF) Conference, 1st September 2006, Bath, UK, 90-91.

Flemming NC. (2011). Research Infrastructure for Systematic Study of the Prehistoric Archaeology of the European Submerged Continental Shelf. In: Benjamin J, Bonsall C, Pickard C and Fischer A. (eds.) Submerged Prehistory. Oxford: Oxbow Books, 287-297.

Fischer A. (2004). Submerged Stone Age - Danish examples and North Sea potential. In: Flemming NC. (ed.) Submarine prehistoric archaeology of the North Sea. Research Priorities and collaboration with industry, CBA Research Report. York: Council for British Archaeology, 23-36.

Fischer A. (2011). Stone Age on the Continental Shelf: an eroding resource. In: Benjamin J, Bonsall C, Pickard C and Fischer A. (eds.) Submerged Prehistory. Oxford: Oxbow Books, 298-310.

Fischer A, Clemmesen LB, Donahue R, Heinemeier J, Lykke-Andersen H, Lysdahl P, Mortensen MF, Olsen J and Petersen PV. (2013). Late Palaeolithic Nørre Lyng by - a northern outpost close to the west coast of Europe. Quartär 60: 137-162.

Galili E and Rosen B. (2011). Submerged Neolithic settlements off the Carmel coast, Israel: cultural and environmental insights. In: Benjamin J, Bonsall C, Pickard C and Fischer A. (eds.) Submerged Prehistory. Oxford: Oxbow Books, 272-286.

Glimmerveen J, Mol D, Post K, Reumer JWF, van der Plicht H, de Vos J, van Reenen G and Pals JP. (2004). The North Sea project: the first palaeontological, palynological, and archaeological results. In: Flemming NC. (ed.) Submarine prehistoric archaeology of the North Sea. Research Priorities and collaboration with industry, CBA Research Report. York: Council for British Archaeology, 43-52.

Gross D, Zander A, Boethius A, Dr eibrodt S, Grøn O, Hansson A, Jessen C, Koivisto S, Larsson L, Lübke H and Nilsson B. (2018). People, lakes and seashores: Studies from the Baltic Sea basin and adjacent areas in the early and MidHolocene. Quaternary Science Reviews 185: 27-40.

Grøn O. (2003). Mesolithic dwelling places in south Scandinavia: their definition and social interpretation. Antiquity 77: $685-708$.

Grøn O. (2012). Our grandfather sent the elk - some problems for hunter-gatherer predictive modelling. Quartär 59: $175-188$.

Grøn O. (2015). A potential for submerged Late Weichselian mammoth-hunter sites in the Scandinavian North Sea sector? Available at: www.academia.edu/15411538/A_potential_ for_submerged_Late_Weichselian_mammoth-hunter_sites_ in_the_Scandinavian_North_Sea_sector $<$ last accessed on 3 June 2018>. 
Grøn O. (2018). Some problems with modelling the positions of prehistoric hunter-gatherer settlements on the basis of landscape topography. Journal of Archaeological Science: Reports 20: 192-199.

Grøn O and Boldreel LO. (2014). Chirping for large-scale maritime archaeological survey: a strategy developed from a practical experience-based approach. Journal of Archaeology: 147390.

Grøn O, Boldreel LO, Cvikel D, Galili E, Hermand J-P and Nørmark E. (2018). Seismic mapping of archaeological pole Structures embedded in sea-floor sediments. In: Proceedings of the 2017 IEEE/OES Acoustics in Underwater Geosciences Symposium (RIO Acoustics), 25-17 July, Rio de Janeiro, Brazil.

Grøn O, Boldreel LO, Cvikel D, Kahanov Y, Galili E, Hermand J-P, Nævestad D and Retian M. (2015). Detection and mapping of shipwrecks embedded in sea-floor sediments. Journal of Archaeological Science, Reports 4: 242-251.

Grøn O and Kuznetsov O. (2004). What is a hunter-gatherer settlement? An ethno-archaeological and interdisciplinary approach. In: The Mesolithic, Proceedings of the XIVth UISPP Congress, 2-8 September, Belgium, BAR International Series 1302. Oxford: BAR Publishing, 47-53.

Grøn O, Nørgård Jørgensen A and Hoffmann G. (2007). Marine archaeological survey by high-resolution sub-bottom profilers. Norsk Sjøfartsmuseums Årbok 2007: 115-144.

Haile J, Holdaway R, Oliver K, Bunce M, gilbert MT, Nielsen R, Munch K, Ho SY, Shapiro B and Willerslev E. (2007). Ancient DNA chronology within sediment deposits: are palaeobiological reconstructions possible and is DNA leaching a factor? Molecular Biology E Evolution 24: 982-989.

Hermand J-P and Tayong R. (2013). Geoacoustic characterization of Stone Age cultural layers: Preliminary FE modelling. In: Proceedings of the MTS/IEEE OCEANS Conference, 10-14 June, Bergen, Norway, 6 pp.

Hermand J-P, Grøn O, Asch M and Ren Q. (2011). Modelling flint acoustics for detection of submerged Stone Age sites. In: Proceedings of the IEEE OCEANS Conference, 19-22 September. Waikoloa, USA, 9 pp.

Inizian M-L, Reduron-Ballinger $\mathrm{M}$, Roche $\mathrm{H}$ and Tixier $\mathrm{J}$. (1999). Technology and Terminology of Knapped Stone. Nanterre: Cercle de Recherches et d'études Préhistoriques. 191 pp.

Jaksland L. (2008). E18 Brunlanesprosjektet. Arkeologiske undersøkelser i Larvik kommune, Vestfold fylke. Årsrapport 2007. Oslo: Museum of Cultural History.

Jaksland L. (2009). E18 Brunlanesprosjektet. Arkeologiske undersøkelser $i$ Larvik og Porsgrunn kommuner, Vestfold og Telemark fylker. Årsrapport 2008. Oslo: Museum of Cultural History.

Jerardino A. (2010). Large shell middens in Lamberts Bay, South Africa: a case of hunter-gatherer resource intensification. Journal of Archaeological Science 37: 2291-2302.

Knapp WR. (2010). Some talk about angles. In Lynn M. (ed.). Flint Knapping. Articles, Tips, and Tutorials from the Internet, 3rd edition: 163-164. Available at: https://www. scribd.com/document/94221050/FlintknappingArticles-Tips-and-Tutorials-From-the-Internet-Lynn <last accessed 1 May 2018>.

Lalonde K, Mucci A, Ouellet A and Gélinas. Y (2012). Preservation of organic matter in sediments promoted by iron. Nature 483: 198-200.

Lejzerowicz F, Esling P, Majewski W, Szczuciński W, Decelle J, Obadia C, Martinez Arbizu P and Pawlowski J. (2013). Ancient DNA complements microfossil record in deepsea subsurface sediments. Biology Letters 9: 20130283.
Lorenz M and Wackernagel W. (1992). DNA binding to various clay minerals and retarded enzymatic degradation of DNA in a sand/clay microcosm. In: Gauthier MJ. (ed). Gene Transfers and Environment. Berlin: Springer, 103-113.

Mol D, Post K, Reumer JWF, van der Plicht J, de Vos J, van Geel B, van Reenen G, Pals JP and Glimmerveen J. (2006). The Eurogeul - first report of the palaeontological, palynological and archaeological investigations of this part of the North Sea. Quaternary International 142-143: $178-185$

Moree JM and Sier MM (eds.). (2015). Twenty metres deep! The Mesolithic period at the Yangtze Harbour site - Rotterdam Maasvlakte, the Netherlands. Early Holocene landscape development and habitation, Interdisciplinary Archaeological Research Programme Maasvlakte 2, Rotterdam, Part 1. Rotterdam: BOOR Rotterdam, 350 pp.

Müller S, Neergaard C, Petersen CGJ, Rostrup E and Winge H. (2002). Kitchen Middens from the Danish Stone Age excavated for the National Museum. In: Fischer A and Kristiansen K. (eds.) The Neolithisation of Denmark. Sheffield: Equinox Publishing, 71-80.

Odum EP and Barrett GW. (2005). Fundamentals of Ecology, fifth revised edition. Boston: Cengage Learning, 624pp.

Parfitt SA, Barendregt RW, Breda M, Candy I, Collins MJ, Coope GR, Durbidge P, Field MH, Lee JR, Lister AM, Mutch R, Penkman KEH, Preece RC, Rose J, Stringer CB, Symmons R, Whittaker JE, Wymer JJ and Stuart AJ. (2005). The earliest record of human activity in northern Europe. Nature 438: 1008-1012.

Parfitt SA, Ashton NM, Lewis SG, Abel RL, Coope GR, Field MH, Gale R, Hoare PG, Larkin NR, Lewis MD, Karloukovski V, Maher BA, Peglar SM, Preece RC, Whittaker JE and Stringer CB. (2010). Early Pleistocene human occupation at the edge of the boreal zone in northwest Europe. Nature 466: 229-233.

Plets RMK, Dix JK, Adams JR, Bull JM, Henstock TJ, Gutowski M and Best AI. (2009). The use of a highresolution 3D Chirp sub-bottom profiler for the reconstruction of the shallow water archaeological site of Grace Dieu (1439), River Hamble, UK. Journal of Archaeological Science 36: 408-418.

Ramos J, Domíguez-Bella S, Cantillo JJ, Soriguer M, Pérez M, Hernando J, Vijande E, Zabala C, Clemente I and Bernal D. (2011). Marine resources exploitation by Palaeolithic hunter-fisher-gatherers and Neolithic tribal societies in the historical region of the Strait of Gibraltar. Quaternary International 239: 104-113.

Rawlence NJ, Lowe DJ, Wood JR, Young JM, Churchman GJ, Huang Y-T and Cooper A. (2014). Using palaeoenvironmental DNA to reconstruct past environments: progress and prospects. Journal of Quarternary Science 29: 610-626.

Richards MP, Jacobi R, Cook J, Pettitt PB and Stringer CB. (2005). Isotope evidence for the intensive use of marine foods by Late Upper Palaeolithic humans. Journal of Human Evolution 49: 390-394.

Romanowski G, Lorenz MG and Wackernagel W. (1991). Adsorption of plasmid DNA to mineral surfaces and protection against DNase I. Applied Environmental Microbiology 57: 1057-1061.

Rust A. (1937). Das Altsteinzeitliche Rentierjagerlager Meiendorf. Neumünster: Karl Wachholtz Verlag, 146 pp.

Rykart R. (1995). Quarz-Monographie - Die Eigenheiten von Bergkristall, Rauchquarz, Amethyst, Chalcedon, Achat, Opal und anderen Varietäten, 2nd edition. Ott Verlag, 414 pp. 
Sahlins M. (1974). Stone Age Economics. London: Tavistock Publications, 348 pp.

Service ER. (1979). The Hunters. New Jersey: Prentice Hall, $105 \mathrm{pp}$.

Shackley MS. (2003). The stone tool technology of Ishi and the Yana. In: Kroeber K and Kroeber C. (eds.) Ishi in ThreeCenturies. Lincoln: University of Nebraska Press,159-200.

Shackleton JC and van Andel T. (1986). Prehistoric shore environments, shellfish availability, and shellfish gathering at Frantchi, Greece. Geoarchaeology 1: 127-143.

Skaarup J. (1995). Stone-age burials in boats. In: CrumlinPedersen $\mathrm{O}$ and Munch Thye B (eds.) The Ship as Symbol in Prehistoric and Medieval Scandinavia. Papers from an International Research Seminar at the Danish National Museum Copenhagen, 5-7 May 1994. Copenhagen: PNM Publications from the National Museum, 51-58.

Skaarup J and Grøn O. (2004), Møllegabet II. A submerged Mesolithic settlement in southern Denmark. Oxford: BAR International Series 1328, 208 pp.

Smith O, Momber G, Bates R, Garwood P, Fitch S, Pallen M, Gaffney V and Allaby RG. (2015). Sedimentary DNA from a submerged site reveals wheat in the British Isles 8000 years ago. Science 347: 998-1001.

Tizzard L, Bicket A and de Loecker D. (2015). Seabed Prehistory. Investigating the Palaeogeography and Early Middle Palaeolithic Archaeology in the Southern North Sea. Wessex Archaeology, 152 pp.

Uldum OC. (2011). The excavation of a Mesolithic double burial from Tybrind Vig, Denmark. In: Benjamin J, Bonsall C, Pickard C and Fischer A. (eds.) Submerged Prehistory. Oxford: Oxbow Books, 15-20.

UNESCO. (2001). Convention on the Protection of the Underwater Cultural Heritage. Paris. van Geel B and Mook WG. (1989). High-resolution 14C dating of organic deposits using natural atmospheric $14 \mathrm{C}$ variations. Radiocarbon 31: 151-155

Wikell R, Molin F and Pettersson M. (2009). The archipelago of eastern middle Sweden - Mesolithic settlement in comparison with C14 and shoreline dating. In: Crombé P, van Strydonck M, Sergant J, Boudin M and Bats M. (eds.) Chronology and Evolution within the Mesolithic of North-West Europe. Proceedings of an international meeting, Brussels 30 May-June 1, 2007. Newcastle: Cambridge Scholars Publishing, 417-434.

Whittaker JC. (2014). The manufacture and use of threshing sledges. In: van Gijn A, Whittaker JC and Anderson PC. (eds.) Exploring and explaining Diversity in Agricultural Technology. Oxford: Oxbow Books, 141-144.

Willerslev E, Hansen AJ and Poinar HN. (2004). Isolation of nucleic acids and cultures from fossil ice and permafrost. TRENDS in Ecology and Evolution 19: 141-147.

Willerslev E, Davison J, Moora M, Zobel M, Coissac E, Edwards ME, Lorenzen ED, Vestergård M, Gussarova G, Haile J, Craine J, Gielly L, Boessenkool S, Epp LS, Pearman PB, Cheddadi R, Murray D, Bråthen KA, Yoccoz N, Binney H, Cruaud C, Wincker P, Goslar T, Greve Alsos I, Bellemain E, Krag Brysting A, Elven R, Sønstebø JH, Murton J, Sher A, Rasmussen M, Rønn R, Mourier T, Cooper A, Austin J, Möller P, Froese D, Zazula G, Pompanon F, Rioux D, Niderkorn V, Tikhonov A, Savvinov G, Roberts RG, MacPhee RDE, Gilbert MTP, Kjær KH, Orlando L, Brochmann C and Taberlet P. (2014). Fifty thousand years of Arctic vegetation and megafaunal diet. Nature 506: 47-51.

Wilmsen EN. (1973). Interaction, spacing behavior, and the organization of hunting bands. Journal of Anthropological Research 29: 1-31. 